Copyright (C) 2021 by Cherkas Global University

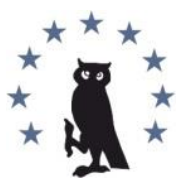

Published in the USA

Russkaya Starina

Has been issued since 2010.

E-ISSN: 2409-2118

2021. 12(2): 102-111

DOI: $10.13187 /$ rs.2021.2.102

https://rs.cherkasgu.press

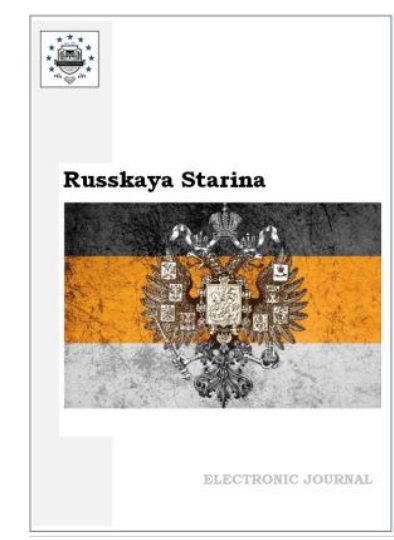

\title{
National Issue on the Pages of the Taganrog Newspaper "Prizyv"
}

Oleg A. Grom ${ }^{\text {a }}$ *

Federal Research Centre the Southern Scientific Centre of the Russian Academy of Sciences, Russian Federation

\begin{abstract}
The article deals with the publications of the newspaper "Prizyv" ("The Appeal"), which is practically not studied in the historiography. "Prizyv" was the first periodical in the Region of the Don Host with strongly pronounced nationalist tendency, printed in Taganrog in 1910-1911. The newspaper propagated so called "economic nationalism" based on the idea of the struggle of Russians with foreigners ("inorodtsy") in trade, industry and agriculture. The Jews, who composed a negligible minority in the region, living mostly in two cities, Taganrog and Rostov-on-Don, were treated by the "Prizyv" newspaper as the main antagonists of the "Russian case". The right-wing publicists imputed to the Jews great ascendancy, especially in the sphere of mass-media. The Armenian problem in the Don was reflected in the debates on the on the so called "Nakhichevan Question" - the project of the accession of Nakhichevan to Rostov-on-Don, which, both right-wing and "progressist" newspapers, were interpreted as a confrontation between the Armenian and Russian parties. The "Prizyv" authors considered the Don Ukrainians (Little Russians), along with the Cossacks, to be an integral part of a great Russian nation, however, unlike most of their colleagues from the nationalist camp in other regions, they left them the right to their own cultural and linguistic identity. Among other non-Russians from the Don and Azovia region (Germans, Greeks, Molokans, etc.), only the Greeks were described as a purely positive element, whose existence did not contradict the "tasks of Russian statehood". The newspaper was closed at the beginning of 1911 due to the plans for the transformation of the publication "Rostovskiy-na-Donu Listok" (Rostov-on-Don Leaflet) into the regional daily newspaper of nationalist orientation.
\end{abstract} "Prizyv".

Keywords: non-Russians, Don region, Nationalism, National Question, Periodicals,

\section{1. Введение}

Начало XX в. стало временем бурного роста периодической печати в России. Вызванные революцией 1905-1907 гг. отмена предварительной цензуры и упрощение порядка регистрации новых изданий привели к значительному росту числа газет и журналов, а также к расширению спектра их социально-политических направлений (Махонина, 2011: 25). Печать освещала широкий круг проблем, актуальных в условиях стремительной модернизации Российской империи в целом, таких, как экономика, политика, местное самоуправление, культура и т.д. Среди важнейших, волновавших русскую

\footnotetext{
${ }^{*}$ Corresponding author

E-mail addresses: gromescu@gmail.com (O.A. Grom)
} 
читающую и пишущую публику, был и национальный вопрос, на общеимперском уровне звучавший в контексте Финляндии, Польши и других окраин. Дебаты по этим проблемам неизбежно проецировались и на местные реалии. Авторы статей в региональных и городских газетах реагировали на события, происходившие в общинах «инородцев» Области войска Донского (ОВД), вступали в полемику по поводу межэтнических взаимоотношений и прав различных этнокультурных групп.

ОВД редко рассматривалась в ряду «национальных окраин», так как согласно господствовавшей идеологеме большой русской нации малороссы, великороссы и казаки совокупно составляли, по данным переписи 1897 г., более 95 \% населения области. Но в то же время, ряд публицистов начала XX в., вне зависимости от того, были ли они сторонниками концепции «большой русской нации» или нет, рассматривали эти группы как вполне самостоятельные, обладающие собственной этнокультурной спецификой и отличными от других интересами в сфере культуры и экономики. По отдельности казаки (лица, приписанные к казачьему сословью), составляли 40 \% населения ОВД, малороссы 28 \%, великороссы (за вычетом казаков) - $27 \%$. Среди «инородцев» наиболее заметными были немцы (1,36\%), калмыки $(1,26 \%)$, армяне $(1 \%)$ и евреи $(0,6 \%)$. В городах доля армянского и еврейского населения была выше (Первая всеобщая перепись, 1905: 78-82).

Публикации в донских газетах по околонациональной проблематике можно разделить на две группы: обсуждение общеимперских, теоретических вопросов и собственно межнациональные отношения в ОВД. Статьи на национальную тематику не были доминирующими в крупных ежедневных газетах, таких, как «Приазовский край», «Южный телеграф», «Таганрогский вестник» и т.д., и появлялись лишь спорадически. При этом материалы, связанные с общеимперскими сюжетами, доминировали. Однако это не являлось следствием какой-либо местной специфики - аналогичная ситуация была характерной и для большинства массовых русских провинциальных изданий, в том числе и выходивших на «классических» национальных окраинах, где нерусские составляли более заметную долю населения, чем в ОВД, а соответствующие «национальные вопросы» стояли более остро.

Среди наиболее значимых всплесков интереса к национальному вопросу в «прогрессивных» газетах Дона и Приазовья можно выделить, например, полемику между А.Б. Тараховским и одним из лидеров таганрогских октябристов П. Неклюдовым по вопросу о роли инородцев в революционных событиях (Приазовский край, 1906. № 4: 3; № 12: 3-4), а также серию публикаций по вопросу о сущности русского национализма и отношения русских к инородцам в «Таганрогском вестнике» в 1912 г. (Таганрогский вестник, 1912. № 17: 3; № 21: 3; № 23: 3). Кроме того, крупные газеты постоянно следили за событиями в националистическом лагере, как на имперском уровне, так и на местном. Редкий номер «Приазовского края» или «Таганрогского вестника» обходился без заметок в стиле «У союзников», «Националисты», рассказов о деятельности правых в Думе и «выходках» крупных лидеров русских националистов, таких, как А.И. Дубровин, В.М. Пуришкевич, М.О. Меньшиков и т.д. Это объясняется, с одной стороны, общим информационным фоном центральных газет, влиявшим на региональные и городские издания, стремившиеся «быть в тренде», с другой, тем, что в прогрессивных изданиях на окраинах среди сотрудников был довольно высокий процент «инородцев», в ОВД, прежде всего, евреев и армян, остро реагировавших антиинородческую риторику правых.

Особняком стояли правые издания, изначально специализировавшиеся на национальной тематике. Как правило, это были газеты и журналы, аффилированные с националистическими и черносотенными организациями, такими, как Всероссийский национальный союз или Союз русского народа. Наиболее значимыми правыми изданиями в регионе были черносотенный «Стяг» (1907), «Ростовский-на-Дону листок» (1909-1917) и «Призыв» (1910-1911).

\section{2. Материалы и методы}

Источником для написания данного исследования выступает издававшаяся в Таганроге в 1910-1911 гг. «еженедельная краевая газета Приазовья и Донской области» «Призыв». Это издание до сих пор остается преимущественно вне поля зрения исследователей. В местной краеведческой литературе газета упоминается редко и, как правило, в связи с личностью одного из ее вдохновителей, краеведа, публициста 
и общественного деятеля А.М. Грекова (Цымбал, 2014; Цымбал, 2015). В статье C.В. Крамской газета упоминается в ряду других правых изданий ОВД, однако непосредственно к материалам газеты автор не обращается, ограничившись анализом «Ростовского-н/Д листка» и просуществовавшей несколько месяцев черносотенной газеты «Стяг» (Крамская, 2016: 152). Ряд публикаций «Призыва», касающихся «немецкого засилья» в сельском хозяйстве ОВД, использован в диссертации О.В. Ерохиной (Ерохина, 2011). Пожалуй, единственной крупной работой, в которой содержание газеты анализируется в контексте формирования националистических организаций на Дону и дебатов по «казачьему вопросу», является монография Б.С. Корниенко «Правый Дон» (Корниенко, 2013: 38-40).

Первый номер «Призыва» вышел 21 февраля 1910 г. (рис. 1). Издателем газеты был Николай Васильевич Кутейников, казачий сотник, дворянин, почетный мировой судья Таганрогского окружного суда. Однако фактическим редактором газеты был известный донской публицист Андрей Михайлович Греков (Греков, 1912: 7). В газете печатались авторы из Таганрога, Новочеркасска и Ростова-на-Дону, причем последние доминировали.

\section{3. Обсуждение и результаты}

В программной статье «Призыва» заявлялось, что одной из основных бед России, мешающих ее обновлению, является упадок патриотизма. В то же время, по мнению издателей газеты, местная печать на 90 \% находится в «нерусских руках». Исправить это положение была призвана новая «национальная» газета (Призыв, 1910. № 1: 1).

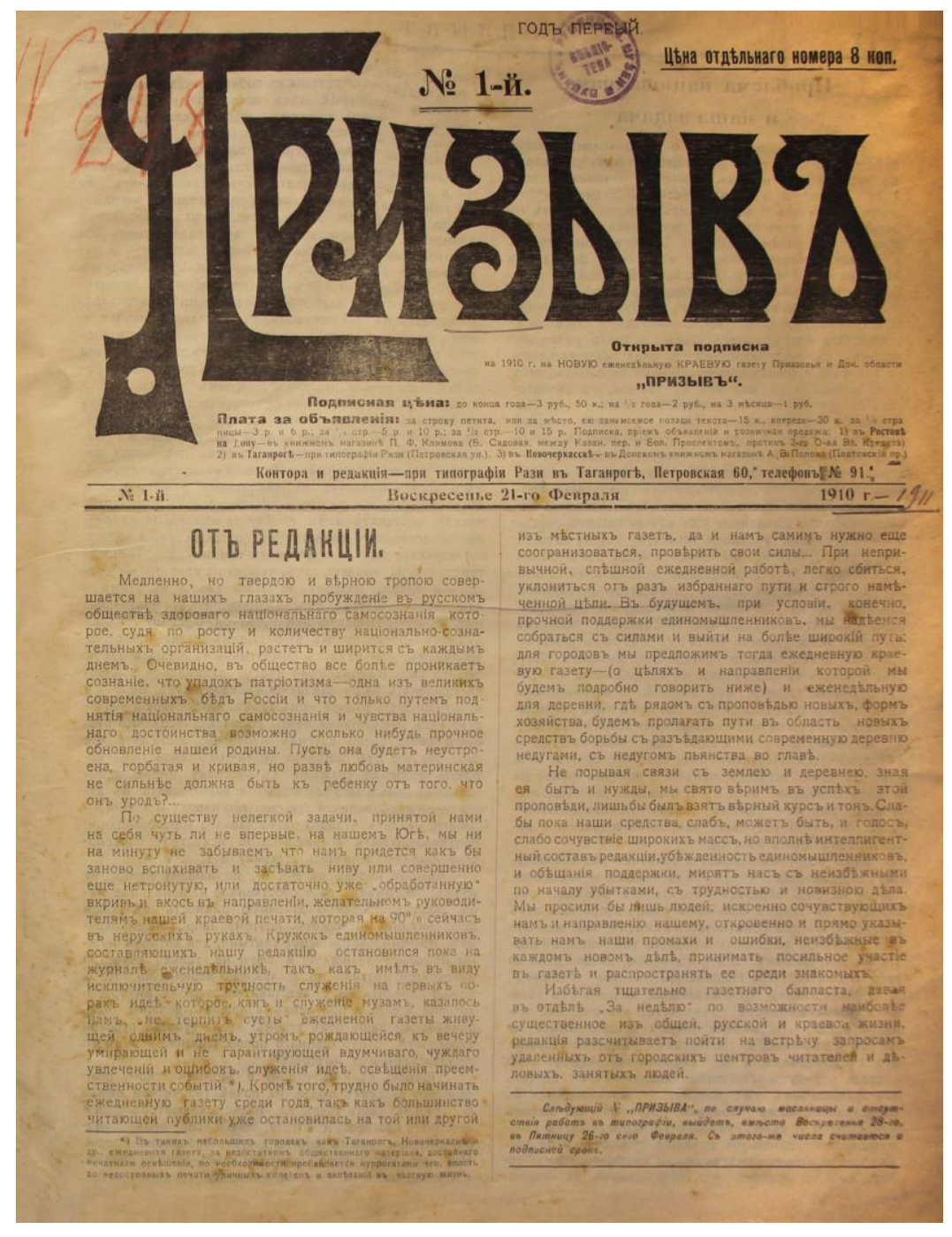

Рис. 1. Страница первого номера газеты «Призыв» 
В статье «Проблема национализма и наша задача» издатели газеты подчеркивали запутанность самой постановки вопроса о национализме в русской прессе. Они предлагали «махнуть рукой» на «расколы северян» (имеется в виду националистическая печать Москвы и Петербурга) и «заняться самим выработкою самостоятельных, по мере разумения нашего, определений и директив в этом вопросе». По мнению кружка издателей газеты, истинный национализм чужд «партийности» и крайних проявлений, различного рода «фобий». Они попытались отмежеваться от деятельности Всероссийского национального союза, так как эта партия, с их точки зрения, рассматривала национализм вне экономического контекста и вывела вопрос в политическое русло. «В лагере, где незыблемо установился девиз "Россия - для русских”, - писала газета, - к нам могут повернуть спину, как к людям, допускающим принцип известных соглашений (не слияний) с инородцами» (Призыв, 1910. № 1: 2). Этот момент отличал «таганрогских националистов» от петербургских и националистов большинства других окраин, крайне неохотно смотревших на перспективы уступок инородцам. Вероятно, в этом нашел отражение полиэтничный характера ОВД в целом и приазовских городов, в частности, где «инородцы», великороссы, малороссы и казаки издавна были переплетены нитями экономических, культурных и зачастую родственных связей.

Ключевым для газеты стал тезис о том, что истинный национализм - это «национализм, поставленный на экономическую или культурную почву». Суть культурной составляющей национализма сводилась к следующей формуле: «любить свои национальные черты; стремиться всячески проявлять наши дарования в творчестве; беречь и культивировать родной наш язык, литературу и искусство, их национальные черты; гордиться успехами русского гения среди других народов; защищать все свое русское от осмеяний публичного свойства; требовать побольше уважения к русскому имени, добиваться национального самосознания; воссоздавать в душе своей как величайшую святыню народа и жизни - религию, культ чудного православного миросозерцания; популяризировать древне-русское искусство, богатырство, былины, живопись, старину и т.д. и т.П.» (Призыв, 1910. № 1: 2).

Экономическая составляющая понималась как «экономическое самоопределение» народов. Здесь газета сразу обозначила предел того, с какими этническими группами сотрудничество донских националистов возможно, а с какими нет: «мы, вероятно, не встретим симпатий лишь со стороны более богатых, более сильных и культурных инородческих групп нашего края, во главе с такими яркими националистами, как евреи, от которых и ожидаем больше всего “ярлыков”, между тем как по существу дела относясь с полным уважением к их национализму и желая даже подражать им, мы вправе были бы ожидать такового и от них» (Призыв, 1910. № 1: 3). Мотив «учиться национализму» и национальной консолидации у евреев, равно как и у других национальных движений, был достаточно характерным рефреном всей русской националистической публицистики. При этом если обратиться к материалам менее предвзятых по отношению к евреям изданий, то можно прийти к выводу, что «еврейская сплоченность» была не более чем мифом.

Из этих программных установок следовало, что аудиторией газеты станет «коренная масса населения, преимущественно средние и мелкие его классы - торговцы, крестьяне, промышленники, экономическим интересом коих угрожают более сильные и старые культурные нации, сильные капиталами, сплоченностью, солидарностью» (Призыв, 1910. № 1: 3).

В либеральном дискурсе начала XX в. за русскими националистами закрепилась репутация противников прогресса, сторонников идеи консервации отживших форм общественного устройства и экономического уклада. Уже в программной статье «Призыва» таганрогские националисты попытались отмежеваться от отождествления их с черносотенцами, а риторика «экономического национализма» была призвана убедить читателей в этом. Отвечая «нашей космополитствующей интеллегенции», не различавшей национализм и черносотенство, газета писала: «Призыв к культурному национализму и экономическому объединению русских людей на почве творческой любви к “своему” есть такой же, надеемся, фактор общественного прогресса и истории, как и усиленные “самоопределения”, коими заняты другие народности России» (Призыв, 1910. № 1: 2). Не отказываясь от идеи «уберечь исторические и культурно-бытовые заветы русской 
народности», издатели «Призыва» приветствовали «всякое прогрессивное начинание, откуда бы оно ни исходило» (Призыв, 1910. № 1: 4).

Важным для публицистов «Призыва» являлся вопрос о том, кто составляет категорию «русских» и, в частности, русских националистов. С одной стороны, постулировалось, что русские интересы могут отстаивать только русские люди, к которым, помимо великороссов, причислялись малороссы и казаки. Газета писала: «Каждый народ в России, по нашему глубокому убеждению, имеет свое собственное национальное лицо, воплощает свою духовную личность в какие-либо святыни: не может, поэтому напр., еврей, охранять искренно устои нашей святыни, для которой нужны не только знания, но и вера, не только “чувство интеллигентности”, но и чувство народности» (Призыв, 1910. № 1: 2). С другой стороны, в статье «Еще о задаче», подписанной псевдонимом «Старый журналист», за которым скрывался Андрей Михайлович Греков (1861-1912) (Борзенко, 2008), говорилось, что «в интересах имперской государственности мы должны дать место среди “своих" и тем обрусевшим инородцам, которые, не являясь носителями чистых начал нашей народности, по духу являются полными нашими единомышленниками» (Призыв, 1910. № 1: 4). Основным «чужим» на страницах газеты станут евреи, что было характерно для правой, националистической периодики. Второй по значимости группой антагонистов донских националистов станут армяне, игравшие заметную роль в культурной, экономической и интеллектуальной жизни Ростова и Нахичевани.

ОВД не входила в черту еврейской оседлости, однако заметное еврейское население было в Ростове и Таганроге, оно осталось «в наследство» от эпохи, когда эти города входили в состав Екатеринославской губернии. Евреи играли важную роль в торговой и культурной жизни приазовских городов. В еврейском вопросе публицисты «Призыва» старались, особенно на первых порах, не выходить за рамки «экономического национализма», рассказывая преимущественно о конфликтах интересов русских и еврейских торговцев, а также о «еврейском засилье» в печати. Однако со временем антисемитская риторика стала выходить за рамки сугубо экономической, газета скатывалась до «измерения черепов» и прочих пассажей в духе «Протоколов сионских мудрецов», характерных для русской черносотенной прессы в целом (Призыв, 1910. № 19: 3). Но все же главным в «еврейском вопросе» признавалась борьба за умы читающей публики. Газета уверяла читателей, что русским торговцам тяжело конкурировать с евреями, а основной причиной этого является то, что местная печать находится в руках евреев. Так, из трех ежедневных ростовских газет, по мнению авторов «Призыва», две были еврейскими, а одна армянской (Призыв, 1910. № 30: 7). Таганрогские газеты также обвинялись в служении «еврейскому делу». Причем если «еврейскую» «Приазовскую речь» упрекали в чрезмерном «охранении чистоты православия» (в газете постоянно публиковались материалы про скандалы, связанные с православной церковью и такими личностями, как Распутин, Илиодор, прот. Воторгов и т.д.; обращение к этим сюжетам было характерной чертой всей тогдашней еженедельной периодики), то «русская газета» «Таганрогский вестник» провинилась в чрезмерном интересе к делам местной еврейской общины (Призыв, 1910. № 19: 6-7).

Помимо «еврейского вопроса» публицисты «Призыва» высказывались и по другим темам, связанным с этническими группами ОВД, среди которых наиболее многочисленной были украинцы, составлявшие большинство населения западной части региона. Украинское движение на Дону было менее развитым, чем в малороссийских и новороссийских губерниях, однако в 1910 гг. в Новочеркасске действовал филиал общества «Просвита» (Плема, 1995), а в городах, так или иначе тяготевших к сельской местности с преимущественно малороссийским населением, огромной популярностью пользовались выступления украинских театральных трупп. Местные газеты постоянно публиковали объявления и отчеты о концертах «малороссов».

В отличие от таких известных своей антиукраинской позицией изданий, как «Киевлянин» или «Окраины России», отношение «Призыва» к особой украинской/малороссийской идентичности было достаточно спокойным. В газете время от времени появлялись вставки и даже отдельные статьи на украинском языке (Призыв, 1910. № 3: 2-3). Примечательно, что издатели газеты во многих случаях при передаче малороссийской речи пользовались не только «ярыжкой» (что было типично для 
большинства правых изданий Российской империи), но и «кулишовкой», более характерной для адептов украинского националистического дискурса.

В заметке «Инородцы ли малороссы?» прослеживаются отголоски дебатов по поводу причисления украинских организаций к инородческим в столыпинском циркуляре от 20 января 1910 г. и думских дебатов по этому поводу. Автор заметки призывает ответить презрением тем русским, кто пытается сеять рознь среди «неделимого единого русского народа», частью которого являются малороссы (Призыв, 1910. № 3: 2).

Украинцы, наряду с «донцами» и великороссами неизменно включались в категорию «наших». Однако таганрогские националисты не настаивали на полной гомогенизации разных «разновидностей русских». Так, в статье «Диспут о “сугубой аллилуйе” или русские ли малороссы?», подписанной псевдонимом Гр-ко, утверждалось, что в России есть только «одна этнографическая разновидность, которая выработалась и продолжает вырабатываться в процессе культурно-исторического развития страны. Эта разновидность есть общерос, который не есть ни великоросс, ни малоросс, ни немец, ни татарин, а продукт совместной исторической жизни и взаимных влияний всех элементов, составляющих Россию» (Призыв, 1910. № 3: 3). «Общерос» - это результат исторически закономерного подчинения «низших» культур «высшим», продукт естественного стремления большинства народов России, в то время как местные и национальные особенности - это лишь «этнографический материал, которые перерабатывается в общероссов». Автор статьи настаивал на том, что для развития малороссийской особой культуры, быта, народного духа и т.д. нет никаких преград, так как, в отличие от 70-х гг. XIX в. (время принятия запретительных мер в отношении украинского языка), в начале XX в. даже допускаются малороссийские школы. Будущее украинской самобытности, по мнению автора, «зависит всецело от их собственных усилий, способностей и симпатий к самобытности, если они есть» (Призыв, 1910. № 3: 4). Более того, Гр-ко подчеркивал, что культурное и экономическое развитие малороссов может и должно сопровождаться развитием их особых черт характера и народного духа, однако оговаривался, что только тех черт, которые являются положительными «с точки зрения русской государственности». Если же интересы малороссийской культуры не будут входить в противоречие с интересами государства, то автор не видел проблемы даже во введении малороссийских школ и развития малороссийской прессы (Призыв, 1910. № 3: 4). Таким образом, «Призыв» в освещении украинского вопроса заметно выделялся на фоне многих других правых изданий России.

Определенный интерес представляет обращение «Призыва» к «армянскому вопросу», выразившееся в серии публикаций по теме проекта присоединения Нахичевани-на-Дону к Ростову. В начале февраля 1910 г. гласный ростовской думы И.С. Кошкин возбудил ходатайство о присоединении города к Ростову. Предложение было поддержано ростовским головой Е.Н. Хмельницким. Нахичеванская дума отнеслась крайне негативно к этой идее, обвинив ростовчан в попытках захвата города, прикрываемых «узконациональной» риторикой (Приазовская речь, 1910. № 84: 3). Интересно здесь использование нахичеванской стороной термина «узконациональный», применявшегося в бюрократическом языке начала $\mathrm{XX}$ в. исключительно по отношению к тем или иным претензиям нерусских народов.

В мае 1910 г. в «Призыве» была опубликована статья «Нахичеванский вопрос», автор которой иронизировал по поводу попыток инородцев и выступивших в их защиту «космополитствующих кадетоидов» отстоять «автономную армянскую республику». Он сравнивал вопрос о «слиянии» двух городов с активно обсуждавшимся в тогдашней печати финляндским вопросом: «Ни дать ни взять - ламентации финляндцев; не достает лишь коллективного вмешательства Европы в Нахичеванский вопрос». По мнению автора заметки, привилегии были даны армянам для развития некогда пустынного края, однако этого развития не произошло и армяне, прикрываясь особым статусом Нахичевани, только паразитируют за счет «русского Ростова». Выступая сторонником идеи «русификации» Нахичевани посредством присоединения ее к Ростову, он приводит пример ликвидации «греческой республики», существовавшего в первой половине XIX в. Мариупольского греческого округа, в 1852 подчиненного общероссийским законам (Призыв, 1910. № 11: 7).

По мнению публицистов «Призыва», слиянию Нахичевани с Ростовом препятствовало именно армянское меньшинство, контролировавшее не только Нахичеванскую, но и, совместно с евреями, ростовскую массовую печать (Призыв, 1910. № 16: 7). Вопрос о статусе 
города подавался, таким образом, как национальный или в духе «экономического национализма», проповедовавшегося газетой, как противостояние интересов инородческого и русского капиталов.

В статье Окшы (псевдоним ростовского фельетониста Сергея Даниловича Окулича) (Борзенко, 2008) проводилась мысль, что революция 1905 г. стала экзаменом на верность для инородцев России. Донские же армяне, по его мнению, этот экзамен провалили, так как они оказались в рядах оппозиции и массово образовывали общества и партии, «враждебные русской государственности». В связи с этим Окулич писал: «Можно ли и должно ли терпеть ту аномалию, тот государственный анахронизм, чтобы кучка народа, в корне враждебного нам, русским, владея клочком русской земли, распоряжалась в нем, командуя почти 30 тысячами русских» (Призыв, 1910. № 30: 5-6).

Интерес в контексте дебатов о донских армянах представляет статья «Нахичеванский вопрос». Цифры и фрагменты текста из статьи встречаются в книге А.М. Грекова «Приазовье и Дон», что указывает на его возможное авторство. По мнению автора, армяне, переселенные на казачьи земли, десятилетиями подрывали благосостояние Юга и государственной казны, а сам «инородческий Нахичевань» был средством отвлечения донцов от моря. Армян, по его мнению, в Нахичевани насчитывалось всего 6оoо, в то время как русское население достигло уже 35 тыс., но армяне, будучи владельцами более дорогих домов, диктовали свою волю русскому населению, которое якобы желало слияния с Ростовом. Однако, стоит заметить, что данные о численности нахичеванских армян, приводимые Грековым и другими публицистами «Призыва», вызывают ряд сомнений. Так, в 1904 г. в городе насчитывалось 20,8 тыс. армян, притом, что русских - 10,8 тыс. человек (Зайцева, 2005: 135-136). В других изданиях фигурировали разные цифры. Тот же ОкшаОкулич в «Ростовском-на-Дону листке» писал о 28 тыс. русских и 12 тыс. армян (Ростовскийна-Дону листок, 1910. № 34: 3). Согласно «Ответу Нахичеванской управы на прошение 35 жителей Ростова о слиянии городов» армянская сторона в целом соглашалась с такой оценкой (Ростовский-на-Дону листок, 1910. № 43: 2). Проблема заключалась в том, что русское население было сконцентрировано на неблагополучных и неблагоустроенных окраинах города, что давало повод для различного рода статистических манипуляций.

К другим народам, населявшим Дон и Приазовье в начале XX в., сотрудники «Призыва» относились преимущественно с антипатией, приводя аргументы экономического характера. Так, в статье «Антинациональная политика» говорилось, что «Юг наш, Приазовье и Донщина стонут от тесноты... Зато купаются в многоземелье немцы, менониты, армяне, антинародные лендлорды новейшей формации - тавричане» (Призыв, 1910. № 2: 1). В газете постоянно публиковались статьи о «засилье» иностранцев разного происхождения, преимущественно немцев-колонистов и бельгийцев, в промышленности и сельском хозяйстве. Крайне негативно группа «Призыва» относилась к немцам, проживавшим в пределах Таганрогского и Ростовского округов. Им вменялось в вину, что они захватывают лучшие земли, ведут более эффективное хозяйство и, самое страшное, «упорно сохраняют свою национальную обособленность от русского народа, к которому они... относятся враждебно, с гордостью и презрением» (Призыв, 1910. № 19: 1). Кроме того, немцы воспринимались националистами как потенциальная пятая колонна, призванная сыграть свою роль в случае войны с Германией (Призыв, 1910. № 19: 3).

Среди диаспорных народов, населявших край, пожалуй, только грекам был открыт путь к сотрудничеству с русскими националистами, о котором они заявили в первых номерах газеты. «Из всех инородцев, живущих в России, - писала газета, - греки ближе всех к нам: во-первых, они православные и, во-вторых, в период несчастной нашей революции они были в стороне, или большею частью действовали заодно с русской национальною партией». Подчеркивалось, что из всех «освобожденных» Россией народов, только греки не требуют «автономий», как это делают финны, грузины и армяне (Призыв, 1910. № 6: 5). Особое отношение к грекам было также следствием таганрогской специфики, где элита имела смешанное греческо-русское происхождение, а люди с греческими фамилиями становились активными деятелями русских националистических организаций, таких, как, например, местный отдел Всероссийского национального союза.

Газета «Призыв» закрылась в начале 1911 г. Редакция сообщала, что в Ростове планируется издание ежедневной национальной газеты на базе «Ростовского-на-Дону 
листка», а издатели «Призыва», «не желая раздроблять силы» переключаются на сотрудничество с новой газетой, которая будет обслуживать интересы всего Приазовья и Дона (Призыв, 1911. 15 янв. Без №: 1). Тем не менее, «Листок», так и не стал ежедневной газетой и не сменил название. По сути, он еще несколько лет так и остался органом ростовских октябристов и умеренных националистов. Газета оставалась скорее ростовской, чем «краевой», на что претендовали издатели «Призыва», а обсуждение на ее страницах национального вопроса, чаще всего ограничивалось армянско-нахичеванской тематикой. Тем самым кратковременное существование «Призыва» с его «экономическим национализмом» и попытками вывети национальную проблематику за узкие рамки политики стало уникальным опытом в истории периодической печати на Дону.

\section{4. Заключение}

Отношение донских правых публицистов, издававших газету «Призыв», к основным этнокофессиональным группам сочетало как типичные идеологемы русского националистического дискурса начала XX в., так и своеобразные трактовки, связанные с местной спецификой. Газета проповедовала «экономический национализм», в основе которого лежала идея борьбы русских с «инородцами» в торговле, промышленности и сельском хозяйстве. Несмотря на то, что националисты воспринимались оппонентами как консерваторы, а зачастую и сами выступали с традиционалистской риторикой, на практике их программа была обращена в будущее, а «национализация» Российской империи выступала непременным условием модернизации. Именно в этом контексте следует понимать логику «экономического национализма».

Евреям, составлявшим в ОВД лишь незначительный процент населения Таганрога и Ростова, однако, по мнению правых публицистов, «захватившим» областную торговлю и «контролировавшим» прессу, отводилась роль главных антагонистов «русского дела». Армянский вопрос нашел отражение в дебатах по «нахичеванскому вопросу» - проекту присоединения Нахичевани к Ростову-на-Дону, который как правые, так и «прогрессивные» газеты трактовали как противостояние «армянской» и «русской» партий. Донских украинцев (малороссов) авторы «Призыва» признавали, наряду с казаками, неотъемлемой частью единой русской нации, однако, в отличие от большинства своих единомышленников из других регионов, оставляли за ними право на культурную и языковую самобытность. Среди прочих «инородцев» Дона и Приазовья только греки описывались как невраждебный элемент, чье существование не противоречило «задачам русской государственности».

\section{5. Благодарности}

Публикация подготовлена в рамках реализации ГЗ ЮНЦ РАН, № гр. проекта ААААA19-119011190182-8

\section{Литература}

Борзенко, 2008 - Борзенко В.В. Псевдонимы донских журналистов и общественных деятелей XIX- начала XX века // Донской временник. 2008. Вып. 16. С. 209-215 [Электронный pecypc]. URL: http://donvrem.dspl.ru/Files/article/m15/1/art.aspx?art_id=956 (дата обращения: 15.10.2021).

Греков, 1912 - Греков А.М. Приазовье и Дон (Очерки общественной и экономической жизни края). СПб.: Общественная Польза, 1912. 208 с.

Ерохина, 2011 - Ерохина О.В. Немецкое предпринимательство в хозяйственном комплексе юга России: 1868-1934 гг.: дис. ... д-ра. ист. наук. Воронеж, 2011. 493 с.

Зайцева, 2005 - Зайцева Н.Н. Нахичевань-на-Дону 100 лет назад // Донской временник. Год 2004-й / Дон. гос. публ. б-ка. Ростов-на-Дону, 2005. Вып. 12. С. 135-136.

Корниенко, 2013 - Корниенко Б.С. Правый Дон: казаки и идеология национализма (1909-1914). СПб.: Изд-во Европейского университета в Санкт-Петербурге, 2013. 223 с.

Крамская, 2016 - Крамская С.В. Деятельность Союза русского народа на Дону (19061916 гг.) // Международный научно-исследовательский журнал. 2016. № 9 (51). С. 151-155.

Махонина, 2011 - Махонина С.Я. История русской журналистики начала XX века. Учебн. пособие. М.: Флинта, Наука, 2011. 240 с. 
Первая Всеобщая перепись, 1905 - Первая Всеобщая перепись населения Российской Империи 1897 г. Т. XII. Область Войска Донского. СПб.: Тип. кн. Мещерского, 1905. 255 с.

Плема, 1995 - Плема С. «Киевлянин» против «Просвиты» // Наше время [Ростов-наДону]. 1995. 28 нояб. [Электронный ресурс]. URL: https://ukr-don.jimdofree.com//статтi/ киевлянин-против-просвиты/ (дата обращения: 11.09.2021).

Приазовская речь - Приазовская речь, газета. Таганрог, 1910.

Приазовский край - Приазовский край, газета. Ростов-на-Дону, 1906.

Призыв - Призыв, газета. Таганрог, 1910-1911.

Ростовский-на-Дону листок - Ростовский-на-Дону листок, газета. Ростов-на-Дону, 1910.

Таганрогский вестник - Таганрогский вестник, газета. Таганрог, 1912.

Цымбал, 2014 - Цымбал А.А. Славный казачий род Грековых в Таганроге // Вехи Таганрога. 2014. № 58. С. 11-16.

Цымбал, 2015 - Цымбал А.А. Все началось с «дневников путешествий» // Вехи Таганрога. 2015. № 62-63. С. 9-15.

\section{References}

Borzenko, 2008 - Borzenko, V.V. (2008). Psevdonimy donskikh zhurnalistov i obshchestvennykh deyatelei XIX- nachala XX veka [Pseudonyms of Don Journalists and Public Figures of $19^{\text {th }}$ and Early 20 ${ }^{\text {th }}$ Century]. Donskoi vremennik. 16: 209-215]. [Electronic resource]. URL: http://donvrem.dspl.ru/Files/article/m15/1/art.aspx?art_id=956 (date of access: 15.10.2021). [in Russian]

Grekov, 1912 - Grekov, A.M. (1912). Priazov'e i Don (Ocherki obshchestvennoi i ekonomicheskoi zhizni kraya) [Pryazovia and Don (Essays of the Public and Economic Life of the Region)]. SPb.: Obshchestvennaya Pol'za, 208 p. [in Russian]

Erokhina, 2011 - Erokhina, O.V. (2011). Nemetskoe predprinimatel'stvo v khozyaistvennom komplekse yuga Rossii: 1868-1934 gg.: dis. ... d-ra. ist. nauk [German Entrepreneurship in the Economic Complex of the South of Russia: 1868-1934. D. dissertation of Doctor of History]. Voronezh, 493 p. [in Russian]

Zaitseva, 2005 - Zaitseva, N.N. (2005). Nakhichevan'-na-Donu 100 let nazad [Nakhichevanon-Don 100 Years Ago]. Donskoi vremennik. God 2004-i. Don. gos. publ. b-ka. Rostov-na-Donu, 12: 135-136. [in Russian]

Kornienko, 2013 - Kornienko, B.S. (2013). Pravyi Don: kazaki i ideologiya natsionalizma (1909-1914) [Right-Wing Don: Cossacks and Ideology of Nationalism (1909-1914)]. SPb.: Izd-vo Evropeiskogo universiteta v Sankt-Peterburge, 223 p. [in Russian]

Kramskaya, 2016 - Kramskaya, S.V. (2016). Deyatel'nost' Soyuza russkogo naroda na Donu (1906-1916 gg.) [The Activities of the Union of the Russian People on Don (1906-1916)]. Mezhdunarodnyi nauchno-issledovatel'skii zhurnal. 9 (51): 151-155. [in Russian]

Makhonina, 2011 - Makhonina, S.Ya. (2011). Istoriya russkoi zhurnalistiki nachala XX veka. Uchebn. posobie [History of Russian Journalism of Early 20 ${ }^{\text {th }}$ Century]. M.: Flinta, Nauka, 240 p. [in Russian]

Pervaya Vseobshchaya perepis', 1905 - Pervaya Vseobshchaya perepis' naseleniya Rossiiskoi Imperii 1897 g. T. XII. Oblast' Voiska Donskogo [The First General Census of the Russian Empire of 1897. Vol. XII. Region of the Don Host]. SPb.: Tip. kn. Meshcherskogo, 1905. 255 p. [in Russian]

Plema, 1995 - Plema, S. (1995). «Kievlyanin» protiv «Prosvity» ["Kievljanin” Against "Prosvita”]. Nashe vremya (Rostov-on-Don). November 28 [Electronic resource]. URL: https://ukrdon.jimdofree.com//statti/kievlyanin-protiv-prosvity/ (date of access: 11.09.2021). [in Russian]

Priazovskaya rech' - Priazovskaya rech', gazeta [“Priazovskaya rech'”, newspaper]. Taganrog, 1910. [in Russian]

Priazovskii krai - Priazovskii krai, gazeta ["Priazovskii krai”, newspaper]. Rostov-na-Donu, 1906. [in Russian]

Prizyv - Prizyv, gazeta ["Prizyv", newspaper]. Taganrog, 1910-1911. [in Russian]

Rostovskii-na-Donu listok - Rostovskii-na-Donu listok, gazeta ["Rostovskii-na-Donu listok", newspaper]. Rostov-na-Donu, 1910. [in Russian]

Taganrogskii vestnik - Taganrogskii vestnik, gazeta [“Taganrogskii vestnik", newspaper]. Taganrog, 1912. [in Russian] 
Tsymbal, 2014 - Tsymbal, A.A. (2014). Slavnyi kazachii rod Grekovykh v Taganroge [Glorious Cossack Family Grekovs in Taganrog]. Vekhi Taganroga. 58: 11-16. [in Russian]

Tsymbal, 2015 - Tsymbal, A.A. (2015). Vse nachalos' s «dnevnikov puteshestvii» [It all Started with "Travel Diaries”]. Vekhi Taganroga. 62-63: 9-15. [in Russian]

\section{Национальный вопрос на страницах таганрогской газеты «Призыв», 1910-1911 гг.}

\section{Олег Андреевич Гром а, *}

${ }^{\text {a } Ф е д е р а л ь н ы и ̆ ~ и с с л е д о в а т е л ь с к и и ̆ ~ ц е н т р ~ Ю ж н ы и ̆ ~ н а у ч н ы и ̆ ~ ц е н т р ~ Р о с с и и ̆ с к о и ̆ ~ а к а д е м и и ~ н а у к, ~}$ Российская Федерация

Аннотация. В статье анализируются публикации практически не изученной в историографии газеты «Призыв», - первого в Области Войска Донского (ОВД) периодического издания националистического направления, выходившего в Таганроге в 1910-1911 гг. Газета проповедовала «экономический национализм», в основе которого лежала идея борьбы русских с «инородцами» в торговле, промышленности и сельском хозяйстве. Евреям, составлявшим в ОВД лишь незначительный процент населения Таганрога и Ростова, отводилась роль главных антагонистов «русского дела». Армянский вопрос нашел отражение в дебатах по «нахичеванскому вопросу» - проекту присоединения Нахичевани к Ростову-на-Дону, который как правые, так и «прогрессивные» газеты трактовали как противостояние «армянской» и «русской» партий. Донских украинцев (малороссов) авторы «Призыва» признавали, наряду с казаками, неотъемлемой частью единой русской нации, однако, в отличие от большинства своих единомышленников из других регионов, оставляли за ними право на культурную и языковую самобытность. Среди прочих «инородцев» Дона и Приазовья (немцы, греки, молокане, «тавричане» и др.), только греки описывались как сугубо положительный элемент, чье существование не противоречило «задачам русской государственности». Газета была закрыта в начале 1911 г. в связи с планами преобразования «Ростовского-на-Дону листка» в ежедневную краевую газету националистической ориентации.

Ключевые слова: инородцы, Область войска Донского, национализм, национальный вопрос, периодические издания, «Призыв».

\footnotetext{
* Корреспондирующий автор

Адреса электронной почты: gromescu@gmail.com (О.А. Гром)
} 